\title{
Popularizing Controversial Science: A Popular Treatise on Poisons by Mateu Orfila (1818)
}

\author{
JOSÉ RAMÓN BERTOMEU-SÁNCHEZ*
}

\section{Introduction}

In the nineteenth century toxicologists participated as experts in criminal poisoning trials and wrote reports at the request of judges and lawyers. In court, they were expected to provide expert advice to lay audiences (juries, judges, lawyers) and, as their conclusions could be decisive in establishing the final verdict, their reports had to be written in a way that was comprehensible to "the unscientific minds of a criminal court and jury". Magistrates and judges thus became potential readers of popular toxicology books. Some of the poisoning trials gained notoriety and were reported in newspapers or reproduced in fiction, thus spreading the interest in toxicology still further. From a more practical point of view, popular books on poisons and antidotes were aimed at a general audience because it was widely acknowledged that appropriate first aid could limit the harm in cases of accidental poisoning. As first aid was usually provided by the family or friends of the unfortunate victim, physicians wrote many books on the subject, explaining to a lay audience what they should do if someone was poisoned. All in all, nineteenth-century toxicologists developed a broad range of popularization practices intended both for the academic community and for the general public. ${ }^{1}$

The aim of this paper is to analyse some problematic issues associated with these practices, by focusing on a very popular nineteenth-century book on toxicology written by Mateu Josep Bonaventura Orfila i Rotger (1787-1853): Secours à donner aux personnes

\section{(C) José Ramón Bertomeu-Sánchez 2009}

*José Ramón Bertomeu-Sánchez, PhD, Institut d'Història de la Ciència i Documentació (Universitat deValència-CSIC), Palau Cerveró, Plaça Cisneros 4, 46003 Valencia, Spain; e-mail: bertomeu@uv.es

The research for this article was partially supported by a grant from the Spanish Ministerio de Educación y Ciencia (HUM2006-07206-C03-02). A previous abridged version of the paper was presented at the fifth Science and Technology in the European Periphery (STEP) Meeting, 'Popularisation of Science and Technology in the European Periphery', Minorca, 1-3 June 2006. I am grateful to all the participants for their helpful comments, especially to Antonio García-Belmar, Josep Simon Castel, Lissa Roberts and Jonathan R Topham. I would like also to express my gratitude to the Medical History anonymous reviewers for their valuable comments and suggestions, and to Gabor Palló and Douglas Carrara for their kind help with the biographies of the Hungarian and Brazilian translators of Orfila's book.

\footnotetext{
${ }^{1}$ Robert Christison, A treatise on poisons, Edinburgh, Adam Black, 1829, p. 195, quoted by I A Burney, 'Bones of contention: Mateu Orfila, normal arsenic and British toxicology', in $\mathrm{J} \mathrm{R}$ Bertomeu-Sánchez and A Nieto-Galan (eds), Chemistry, medicine and crime: Mateu Orfila (1787-1853) and his times, Sagamore Beach, Science History Publications/USA, 2006, pp. 243-59. For the different meanings of poisons, see B Wahrig, 'Organisms that matter: German toxicology (1785-1822) and the role of Orfila's textbook' ibid., pp. 153-82. On the broad interest in poisons in the nineteenth-century, see, for instance, the analysis of British and US crime literature and other popular writings on poisons by I A Burney, Poison, detection, and the Victorian imagination, Manchester University Press, 2006; and Mark R Essig, 'Science and sensation: poison murder and forensic medicine in nineteenth-century America', doctoral thesis, Cornell University, 2000.
} 


\section{José Ramón Bertomeu-Sánchez}

empoisonnées et asphyxiées (A popular treatise on the remedies to be employed in cases of poisoning and apparent death) published in 1818. ${ }^{2}$ Born in Menorca, trained in Spain and France, Mateu Orfila became a leading figure in the Paris medical milieu during the 1830s and 1840s. Dean of the Paris Medical Faculty, founder member of the Academy of Medicine, author of several reference books on toxicology, editor of such influential medical journals as Annales d'Hygiène Publique et de Médecine Légale, expert witness in many popular poisoning trials, Mateu Orfila was an outstanding figure in nineteenthcentury European medical circles, and his work had a profound impact in moulding the public perception of forensic medicine. ${ }^{3}$ The first section of this study presents biographical information on the author, focusing particularly on why he decided to publish his work and why it met with such success in no more than a few years (four editions were published as well as numerous translations into German, Spanish, Italian, Danish, Portuguese and English). The next section charts how the book's intended audience changed in the later editions and discusses the boundary work done by the author in defining the limits of the realm of physicians' practice and that of quacks and popular healing. The following sections discuss the contents of the book and the controversies surrounding it. Nineteenth-century toxicology was far from being a consensual body of knowledge accepted by a homogeneous expert community. Contrasting points of view were held on key questions such as the action of poisons, the choice of antidotes, and the uses of animal experimentation, as will be discussed in the following pages. Needless to say, these controversies undermined public confidence in toxicologists both as courtroom experts and as writers of popular books on poisons. Finally, the paper will consider how these issues were perceived in different contexts via an analysis of the translations and the degree of creativity displayed by some of the translators. The paper thus deals with three topics which have been explored in depth by historians in recent decades: popularization, controversies, and the circulation of knowledge. ${ }^{4}$

\footnotetext{
${ }^{2}$ The English translation of the title is taken from the London edition (translated by William Price, 1818). In the following pages, the editions of Secours will be referred to by the year and, if known, by translator, for instance, Orfila/Price, 1818. See Appendix for more information.

${ }^{3}$ On Orfila, see Bertomeu-Sánchez and NietoGalán (eds), op. cit., note 1 above. A chronology of his life, a comprehensive bibliography, a list of editions and translations of Orfila's books and electronic versions of some of them are available at http://www.bium.univ-paris5.fr/histmed/medica/ orfila.htm. Several editions of the Secours are available there.

${ }^{4}$ Many papers have been published on each of these topics. See, for instance, the surveys by J Golinski, Making natural knowledge:

constructivism and the history of science, Cambridge University Press, 1998; and K Gavroglu, O passado das ciências como história, Lisboa, Porto Editora, 2007. On popularization, see R Porter (ed.), The popularisation of medicine, 1650-1850, London and New York, Routledge, 1992; R Cooter and
}

S Pumpfrey, 'Separate spheres and public places: reflections on the history of science popularization and science in popular culture', Hist. Sci., 1994, 32: 237-67; B Bensaude-Vincent, L'opinion publique et la science, Paris, Sanofi-Synthélabo, 2000; and J Topham, 'Rethinking the history of science popularisation/popular science', in F Papanelopoulou, A Nieto-Galan, and E Perdiguero (eds), Popularizing science and technology in the European periphery, 1800-2000, Ashgate, Aldershot, 2009, pp. 1-20. On controversies, H T Engelhardt and A L Caplan (eds), Scientific controversies: case studies in the resolution and closure of disputes in science and technology, Cambridge University Press, 1987; and D Raynaud, Sociologie des controverses scientifiques, Paris, PUF, 2003. On the ways that knowledge travels, see J A Secord, 'Knowledge in transit', Isis, 2004, 95: 654-72, and the meetings and books published by the group STEP (Science and Technology in the European Periphery), summarized in K Gavroglu, M Patiniotis, F Papanelopoulou, A Simões, et al., 'Science and technology in the European periphery: 


\section{A Popular Treatise on Poisons by Mateu Orfila (1818)}

\section{Poisons, Music, and Salons}

Mateu Orfila was born in Mahon (Menorca) on 24 April 1787. Educated by French and English tutors, his knowledge of foreign languages would later enable him to read the most important scientific literature of the age. According to his autobiography, he studied mathematics, natural science and music from a very early age, and sang in a choir in order to correct his stutter. ${ }^{5}$ In September 1804, Orfila travelled to Valencia and entered the Faculty of Medicine but, disappointed by the intellectual atmosphere there, he moved to Barcelona and later to Paris, thanks to a grant (pensión) offered by the Catalan Junta de Comerç de Barcelona. ${ }^{6}$ In Paris, Orfila enrolled as a student at the Faculty of Medicine and obtained his doctoral degree in 1811. He also met Antoine-François Fourcroy and Nicolas Vauquelin, two leading French chemists, who admitted him to their teaching laboratories. Like other Spanish students, Orfila attended Louis-Jacques Thénard's chemistry courses at the Collège de France. ${ }^{7}$ Moreover, very soon after his arrival in Paris, and with the help of a rich friend, Orfila started to lecture on chemistry and other sciences. His first private courses were free and attended by a small number of students, but he soon gained popularity in the large market of private science courses in the French capital. Between May and August 1811, Orfila passed the exams leading to the degree of doctor in medicine and, in December of the same year, he submitted his doctoral thesis on the analysis of the urine of persons affected by jaundice. ${ }^{8}$

Once he had finished his medical studies, there was no reason for Orfila to stay in Paris. However, ignoring the wishes of his family, he decided to continue his successful lectures and to try to make a living inside the competitive Parisian market of private science classes. In the same month, December 1811, he started a new course in medical chemistry in the Rue Croix-des-Petits-Champs, a street located between the rear part of what today is the Louvre Museum and the Place des Victoires. Orfila had some forty students who paid him the sum of forty francs each. Thus, in total, he earned about 1,600 francs, which was roughly what he had received as his grant from the Barcelona Junta de Comerç when he first arrived in Paris. ${ }^{9}$ Among the students were colleagues of his who would become influential doctors and teachers at the Faculty of Medicine: Pierre Augustin Béclard, subsequently professor of anatomy, to whom Orfila dedicated the third edition of his Elémens de chimie, and the brothers Hippolyte and Jules Cloquet, who helped to popularize Orfila's works by publishing favourable reviews in medical

some historiographical reflections', Hist. Sci., 2008, 46: $153-75$.

${ }^{5}$ Orfila, autobiography, reproduced in M G Chapel d'Espinassoux (ed.), 'La jeunesse d'Orfila. Fragment d'une autobiographie inédite publié par ...', Revue Hebdomadaire, 1914, 22-3: 615-34, 86-113, on p. 620.

${ }^{6}$ See A García-Belmar and J R BertomeuSánchez, 'Constructing the center from the periphery. Spanish travellers to France at the time of the chemical revolution', in A Simões, A Carneiro, M P Diogo (eds), Travels of learning: a geography of science in Europe, Dordrecht, Kluwer Academic, 2003, pp. 143-88.

\footnotetext{
${ }^{7}$ See A García-Belmar, 'The didactic uses of experiment: Louis-Jacques Thénard's lectures at the Collège de France', in Bertomeu-Sánchez and NietoGalan (eds), op. cit., note 1 above, pp. 25-53.

${ }^{8} \mathrm{M}$ Orfila, Nouvelles recherches sur l' urine des ictériques, ... Paris, Didot jeune, 1811.

${ }^{9}$ The data on Orfila's courses and the fees he charged come from both his autobiography and his correspondence. See letter from Orfila to his mother, 16 Feb. 1812, Biblioteca de Catalunya, MS. 3150, reproduced in M C Bosch, 'Contribució a l'epistolari d'Orfila', Randa, 1988, 30: 133-76, pp. 156-7. The details of the grant are found in his autobiography, see Chapel d'Espinassoux (ed.), op. cit., note 5, p. 633.
} 


\section{José Ramón Bertomeu-Sánchez}

journals. Some years later, Orfila worked with them on the publication of several medical dictionaries. Another of Orfila's students and friends at this time was WilliamFrédéric Edwards, who obtained his doctorate in medicine at the Paris Faculty in 1815 and wrote various studies on new experimental physiology. Orfila dedicated some grateful words to Edwards in his book on toxicology, mentioning his colleague's contribution to the project.

Encouraged by his success and protected by this group of friends who would play such an important part in the development of his career, Orfila moved to the Rue des Fossés Saint-Jacques, on the other bank of the Seine and closer to the Faculty of Medicine, where his potential public was to be found. Here, in the summer of 1812 , he started to give courses in science, including chemistry, legal medicine, anatomy and botany. He repeated these lectures for some years until 1819, when he was made a professor at the Faculty of Medicine. It was before Orfila began his brilliant career at the Faculty that he published his main works: the Traité des poisons, and Elémens de chimie. ${ }^{10}$

According to Orfila's memoirs, an incident in one of his courses led to one of his most important discoveries in toxicology. While lecturing on arsenic in April 1813, he obtained the precipitates that characterize this substance in front of his students and affirmed categorically that the same result would be obtained when the poison was mixed with organic fluids, broth, or drinks like coffee or wine. Orfila took a cup of coffee, tipped the arsenic solution into it and repeated the experiment. To his surprise, the lime reagent produced a violet-grey precipitate instead of the white colour he had expected, and the ammoniac copper sulphate caused some deposits of a dark olive colour instead of the green typical of its reaction with arsenic. ${ }^{11}$ Orfila worked on the problem during the months that followed and carried out many experiments with chemical reagents and poisons mixed with organic substances. He also compiled clinical data on symptoms of poisoning and the anatomical damage found in post-mortem autopsies. He performed many experiments with dogs, varying the quantity of poison and the route of administration, and testing antidotes and treatments. With this information, he wrote his Traité des poisons and signed a contract with Nicolas Crochard, the publisher of the influential journal Annales de Chimie, according to which Crochard agreed to pay Orfila 5,000 francs (that is, roughly four times the income Orfila earned from his lectures in 1811/12) for a two-volume book. The first edition (1,500 copies) was favourably received by the medical community. A second edition was rapidly printed, followed by three more. The book was translated into English, German, Italian and Spanish, and was the principal reference work on toxicology during the forty years between the first and last editions. While preparing the second edition, Orfila extracted the sections on antidotes and treatments for poisoning and published them in a small format, low-cost book, which he called Secours à donner aux personnes empoisonnées et asphyxiées. It soon became a great success and, thus, another important source of income. ${ }^{12}$

\footnotetext{
${ }^{10}$ For more details on the context of the publication of these works, see B Bensaude-Vincent, A García Belmar and J R Bertomeu Sánchez, L'émergence d'une science des manuels: les livres de chimie en France (1789-1852), Paris, Editions des Archives Contemporaines, 2003.
}

\footnotetext{
${ }^{11}$ Chapel d'Espinassoux (ed.), op. cit., note 5 above, p. 96.

${ }^{12}$ For a list of the different editions, see http:// www.bium.univ-paris5.fr/histmed/medica/orfila.htm.
} 


\section{A Popular Treatise on Poisons by Mateu Orfila (1818)}

Orfila's fame as a toxicologist had grown. In 1815, he was elected membre correspondant of the Paris Academy of Science (Institut de France) ${ }^{13}$ and he obtained a position as royal physician (médecin par quartier du Roi). In 1819, he was appointed professor of legal medicine at the Paris Faculty. Orfila was gifted not only in medicine and chemistry, but in music as well. He frequented several Parisian salons and he was in great demand as a singer, sometimes performing musical duos with his future wife, Gabrielle Lesueur. In 1814, Orfila attended the soirées of the Princesse de Vaudémont "twice a week". The Princesse de Vaudémont ran one of the most popular and influential Parisian salons, frequented by people from different walks of life, countries and political parties, including physicians, artists and writers; tea and ices were served and, at the end of the evening, some punch. ${ }^{14}$ She also organized musical evenings at which Orfila was one of the regular performers. The young physician had a remarkable voice and it was even said that "offers had been made to him to exchange the amphitheatre and the lecture room for the boards of the opera". ${ }^{15}$ Orfila soon realized that his talent for music, put to good use in the Parisian salons, was an excellent way to gain fame and fortune in early nineteenth-century France. In a letter addressed to his father in 1814, he wrote:

Here I meet people of distinction such as Counts, Dukes, Marquises and others. The people I know best are Princess Vaudémont and Prince Talleyrand. I eat twice a week at the Princess's home and she regards me as a son. She is the cousin of the Emperor of Austria and a very rich and graceful woman. Let me tell you how I met her. I have been naturally gifted with a superb voice, I have such a great disposition toward music that I have always found time for singing, in spite of my many everyday duties. I have improved little by little [my voice], so much so that nobody in Paris sings better than I.... All the wealthy people of Paris who are music lovers would like to have me in their houses, but I do not go: I sing only at the Princess's home. She loves music immensely and she has put me in touch with several physicians and persons who have been, and may still be on occasion, enormously helpful. ${ }^{16}$

${ }^{13}$ Académie des Sciences, Dossier Orfila.

${ }^{14}$ See P Mansel, Paris between empires: monarchy and revolution 1814-1852, New York, St Martin's Press, 2003, pp. 132-5.

${ }^{15}$ The sentence was written by the American physician Peter Solomon Townsend in his diary, in 1828. See G Rosen, 'An American doctor in Paris in 1828: selections from the diary of Peter Solomon Townsend, M.D.', J. Hist. Med. Allied Sci., 1951, 6 (1): 64-115, p. 81.

${ }^{16}$ Letter from Orfila to his father, 1 May 1814 , published by F Hernández Sanz, 'Tres cartas inéditas del Dr. Orfila (1809-1814-1815)', Revista de Menorca, 1899: 163-76, pp. 173-4 (my italics). The extract deserves to be reproduced in extenso: "Aquí conozco gentes de primera condición Condes, Duques, Marqueses y otros. Las personas que conozco más particularmente son la Princesa de Vaudemont y el Príncipe Thalleyrand [sic] Como seguramente dos veces por Semana en casa de la Princesa que me mira como su hijo. Esta Señora es Prima del Emperador de Austria, Muger de mucho garbo y riquísima. Voy a decir a V. cómo la he conocido. La naturaleza me ha favorecido con una voz soberbia, mi inclinación para la Música ha sido tal que en medio de mis ocupaciones siempre he encontrado ratos para cantar; poco a poco he adquirido tanto que hoy en día no hay en París quien cante como yo (la Música Italiana q[u]e es la mejor). Sírvase V. creer que no digo esto por vanidad, con V. debo hablar claramente; nada debo ocultar, sabe Dios $\mathrm{q}[\mathrm{u}] \mathrm{e}$ a nadie escribiría de esta suerte. Todos los ricos de esta Ciudad que son aficionados desearían que fuera a sus casas, pero yo nada de esto hago; solo canto en casa de d[ic]ha Princesa a quien le gusta infinito la música; ella es la que me ha hecho conocer varios Médicos y Sugetos que me han sido y podrán serme útiles. En este Pays se piensa un poco diferente de nuestra España. Un hombre de primer mérito en qualquier ramo que sea goza de muchísima consideración y es honrado, p[or] ex[emplo], se hace aquí el mismo caso de un excelente médico como de un excelente Pintor o Escultor o de un Príncipe, la verdadera nobleza es el talento; de aquí debe $\mathrm{V}$. inferir que cantando delante de gentes que me conocen como Médico y Profesor, lexos de ser malvisto, todos me estiman mucho más porque se aturden al ver que dos ramos tan distintos la Música 


\section{José Ramón Bertomeu-Sánchez}

In the same letter, Orfila told his father that in France "talent" was "considered to be the true nobility". And he added that "singing for people who know me as a physician ... is anything but improper ... everybody holds me in great esteem because they are surprised that fields so different as music and medicine can be associated without difficulty". ${ }^{17}$ In the salons, Orfila met many physicians and politicians whose support and influence would prove decisive in his future career as a toxicologist. ${ }^{18} \mathrm{He}$ even told one of his colleagues at the Faculty of Medicine that he had "obtained more advantageous decisions for the Faculty" and "succeeded in more projects relative to research in salons than in the proceedings of commissions and in government offices". ${ }^{19}$ Other sources show that the social life in Parisian salons is indeed very important for an understanding of the success of Orfila's popular book on poisons. It was probably during one of the musical soirées that Orfila met Comte Louis Mathieu Molé, one of Louis XVIII's ministers, whose support was crucial for the publication and spread of the Secours. Comte Molé used to frequent the salons of both the Duchesse de Duras (also visited by politicians and scientists such as Georges Cuvier and Alexander von Humboldt) and the Princesse de Vaudémont; ${ }^{20}$ Orfila mentioned him in his autobiography as one of the most influential personages he had met at the salons. ${ }^{21}$ In April 1818, Mole wrote to the Minister of the Interior to ask him to support a previous request by Orfila concerning his popular book on poisons. ${ }^{22}$

Two days earlier Orfila had himself written to the Minister with the request that the Paris Faculty of Medicine might review his book. If the review was positive, Orfila asked the Minister to "buy a certain number of copies and to recommend it to all the mayors of

y la Medicina pueden asociarse sin detrimento alguno. En suma sé arreglarme, y nada hago que me sea perjudicial. El Principe Thalleyrand es hoy en día la primera persona de Francia después del Rey, será probablemente Gran Ministro de Francia; es el primer diplomático del mundo, hombre de un talento raro. Este me quiere y voy también a su Casa."

${ }^{17}$ Ibid. p. 173.

${ }^{18}$ In his autobiography, he acknowledged that these relationships became "extremely useful" during his subsequent professional life; Chapel d'Espinassoux (ed.), op. cit., note 5 above, pp. 106-7. "L'attrait qu'avait pour moi ce salon [Princesse de Vaudémont] était tel qu'il m'absorbait tout entier et que je ne quittais presque jamais mon foyer domestique que pour m'y rendre. C'est dans cette période de ma vie et dans cette maison si célèbre que j'ai connu tout ce que la capitale renfermait de distingué; les relations que j'avais établies avec la plupart de ces hommes puissants, m'ont été extrêmement utiles au courant de ma vie administrative, pour surmonter les obstacles que, sans cela, j'aurais eu de la peine à vaincre pour mener à bonne fin mes divers projets d'amélioration des études médicales."

${ }^{19}$ P H M Bérard, Eloge d'Orfila prononcé dans la séance de rentrée de la Faculté de médecine, Paris,
Labé, 1854, p. 50: "J'ai obtenu plus de décisions avantageuses pour la Faculté, j'ai mené à bonne fin plus d'entreprises relatives aux études, dans les salons que dans les bureaux des administrations. Cet aveu scandalisera peut-être ces hommes qui cherchent dans un maintien austère et l'ennui qu'ils infligent une sorte d'appoint à une réputation d'administrateur ou de savant; mais les succès dans le monde ne pouvaient être compromettants pour celui que tant de travaux sérieux et utiles recommandaient à l'estime des véritables savants et à la reconnaissance publique." See also A Fayol, La vie et l'oeuvre d'Orfila, Paris, Albin Michel, 1930, ch. 12, pp. $130-43$.

${ }^{20}$ Mansel, op. cit., note 14 above, pp. 138-9.

${ }^{21}$ Chapel d'Espinassoux (ed.), op. cit., note 5 above, pp. 104-6.

${ }^{22}$ Archives Nationales de France (ANF), F8/161, Note, 24 April 1818. "Voici mon cher et honorable collègue la demande de $\mathrm{M}$. Orfila je ne vous cache pas que c'est moi qui l'ai provoquée. Il m'a paru digne de votre administration de protéger et de répandre un ouvrage que recommande également le nom de son auteur et le but dans lequel il est entrepris ...". 


\section{A Popular Treatise on Poisons by Mateu Orfila (1818)}

the kingdom". ${ }^{23}$ The book was reviewed very favourably by the members of the Faculty of Paris. In the report, read at the session of 14 May 1818, Nicolas Vauquelin noted that "the utility" of Orfila's book was "so evident" that it was "unnecessary to dwell upon the subject". ${ }^{24}$ After describing the contents of the book, the report recommended that the "Government ... take the necessary measures to distribute it among any class of society, and especially that it may be in the hands of medical men, the clergy, the municipal officers, to whom it has become indispensable to make known the progress science has made of late years" in the treatment of poisoned and asphyxiated persons. ${ }^{25}$ With such a positive review (which he included at the beginning of the book) Orfila wrote to the Minister again:

The desire to make a useful contribution by popularizing knowledge which is so closely related to the conservation of human health, [and, at the same time], to obtain an indemnification for the considerable expenses that I was obliged to incur during the period of six years in order to give this treatise the degree of perfection I could achieve, are the reasons that moved me to print several thousand copies. I dare to flatter myself that your Excellency might deign to take appropriate measures so that the book may be sent to the mayors and priests of the kingdom, as well as to the courts. $^{26}$

He announced that the book would be ready for publication by the end of May $1818 .{ }^{27}$ The printer's official statement refers to a print run of 4,000 $\operatorname{copies}^{28}$ but, according to Orfila's autobiography, 10,000 copies were in fact published. ${ }^{29}$ Although Orfila maintained his association with the publisher-bookseller Nicolas Crochard, he announced on the title-page that the book would be sold at his own house, which suggests that he expected to obtain a substantial income from it, perhaps more than the 5,000 francs he had gained for his first book. ${ }^{30}$ The possibility of making a substantial profit by publishing a popular book on poisons is confirmed by William Price, one of the book's translators. Just a few days before the publication of the first edition, Price wrote a letter to a London publisher and bookseller, in which he mainly discussed the "pecuniary arrangements" and the different ways in which the book might be sold: by subscription,

${ }^{23}$ ANF, F8/161, Paris, 22 April 1818. “... se faire rendre compte par la Faculté de Médecine du mérite de cet ouvrage, et dans le cas où le rapport serait avantageux, de vouloir bien souscrire pour un certain nombre d'exemplaires et de recommander à tous les maires du Royaume par une circulaire".

${ }^{24}$ Bulletin Société de la Faculté de Médecine, 1818, 3: 127-9. Sessions of 1 and 14 May. The report was printed in several medical journals. Nouveau Journal de Médecine, Chirurgie, Pharmacie, 1818, 1: $378-80$.

${ }^{25}$ Cf. Orfila, 1818 , pp. ix-x. Translation from Orfila/Black, Baltimore, 1819, p. xiv.

${ }^{26}$ ANF, F8/161, Paris, 18 May 1818. "Le désir de me rendre utile en popularisant des connaissances qui touchent de si prés à la conservation de l'homme, et de trouver un dédommagement des frais considérables que j'ai été obligé de faire pendant six ans, pour donner à ce traité le degré de perfection auquel il m'était permis d'atteindre tel est le motif qui m'a engagé à en imprimer plusieurs milliers d'exemplaires. J'ose me flatter que v. Exc. daignera prendre les mesures convenables, pour qu'il voit déposé chez les Maires et les Curés du Royaume, ainsi que dans les tribunaux."

${ }^{27}$ Ibid. "l'ouvrage pourra être mis en vente du 25 au 28 du courant."

${ }^{28}$ ANF, F18/77, The printer's statement was signed on 6 May 1818.

${ }^{29}$ Regarding the first edition of the Secours, Orfila said that: "la première édition a été tirée à dix mille exemplaires" (Chapel d'Espinassoux (ed.), op. cit., note 5 above, p. 99).

${ }^{30}$ The book could be obtained "A Paris, chez l'Auteur, rue des Fossés-Saint-Germain-des-Près, n. 14; Crochard, libraire, rue de Sorbonne, n. 3; et Desoër, libraire, rue de Christine, $n^{\circ} 2$." The price was $3 \mathrm{fr}$, or $3 \mathrm{fr} .50$ cent. (including postage). 


\section{José Ramón Bertomeu-Sánchez}

in the form of a private edition, via agreements with booksellers, or (the method he seemed to prefer) via a partnership with the publisher, in which he suggested that the profits (sales minus publishing costs) might be "divided ... in proportions to be agreed". ${ }^{31}$ Clearly, Orfila and his translator regarded the publication as a very lucrative activity.

Books on poisons, first aid and antidotes were popular at the beginning of nineteenth century. ${ }^{32}$ In Paris, books similar to Orfila's had recently been published by Antoine Portal and Hector Chaussier. Portal was a very well-known and respected physician who gave lectures on anatomy at the prestigious Collège de France. He published several books on first aid, which had been reprinted a number of times since the late eighteenth century with the support of the government. ${ }^{33}$ Chaussier was the son of a famous professor of medicine and had published a book on antidotes in early $1818 .^{34}$ In the second edition, which was published the same year, he accused Orfila of plagiarism:

In January 1818, I published the first edition of this textbook under the title of Contre-Poisons [Antidotes]; I dedicated it to M. Orfila who had published a work on the various species of poisons, without indicating any curative means; I addressed a copy of my Contre-poisons to this enlightened physician, who, undoubtedly too busy, neglected to acknowledge receipt of it; but, three months later, he dealt with the same subject as my work, and the resemblance of our works was so complete, even in the errors, a circumstance of which I was very flattered ... ${ }^{35}$

Chaussier's book and Orfila's Sécours were indeed quite similar from the point of view of their contents, aims, and target audience. Moreover, both authors published their books themselves, so, like the translator mentioned above, they expected to make a substantial profit, and both were eager to obtain the support of the Ministère de

\footnotetext{
${ }^{31}$ Wellcome Library, Ms 7375 /217, Letter from William Price to William Phillips, Paris, 6 June 1818

${ }^{32}$ For a contemporary list, see Marcus S Krüger, Handbuch der Literatur für die praktische Medicin und Chirurgie, Berlin, Richter, 1842, pp. 436-8.

${ }^{33}$ Portal was professor of anatomy at the Collège de France and at the Jardin du Roi. See E H Ackerknecht, Medicine at the Paris hospital, 1794-1848, Baltimore, Johns Hopkins Press, 1967, p. 26. Portal published several books on first aid, among them Instruction sur les traitemens des asphixiés par le méphitisme, des noyés, des personnes qui ont été mordues par des animaux enragés, Paris, Régent et Bernard, 1795 [an IV]. The book was reprinted several times and a new edition appeared just two years before the publication of Orfila's book (see A Portal, Traitement des asphyxiés, Paris, 1816).

${ }^{34} \mathrm{H}$ Chaussier, Contre-poisons, ou moyens reconnus les plus efficaces pour combattre l'effet des diverses espèces de poisons, Paris, L'auteur, 1818. The third edition was announced in 1819. And the fourth edition was published in 1836 by Roret. Hector Chaussier had been "éditeur scientifique" of the journal L'Ami des Arts (1795) and he had published
}

several political leaflets but no scientific books. He may have been a relative of François Chaussier (1746-1828) who was professor of the Paris Faculty of Medicine and published several books on legal medicine.

${ }^{35}$ Chaussier, Contre-poisons, 2nd ed. 1818, pp. 1-2: “Au mois de janvier 1818, j' ai fait paraître la première Edition de ce Manuel sous le titre de Contre-Poisons; je l'ai dédiée à $\mathrm{M}$. Orfila qui avait publié un Ouvrage sur les diverses espèces de poisons, sans indiquer aucun moyen curatif; j'ai adressé un exemplaire de mes Contre-poisons à ce savant Docteur, qui, trop occupé sans doute, a oublié de m'en accuser la réception; mais, trois mois après, il a traité le même sujet que moi, et la ressemblance de nos Ouvrages s'est trouvée complète, même dans les erreurs, circonstance dont j'ai été très flatté... . Pour me justifier à cet égard, il me suffit de rappeler la première Edition des Contre-Poisons: elle est antérieure à l'Ouvrage de M. Orfila; je n'ai pas pu copier celui qu'il a publié trois mois après le mien. On ne doit donc pas s'écrier en me lisant: O IMITATORES SERVUM PECUS!". Ironically, the first edition was dedicated to "Monsieur Orfila ". 


\section{A Popular Treatise on Poisons by Mateu Orfila (1818)}

l'Intérieur. ${ }^{36}$ Finally, and most probably thanks to the support of Comte Molé, the Minister agreed to buy 250 copies of Orfila's book and for it to be "sent to the Prefects in order to be placed in libraries or to be distributed to the principal physicians or surgeons; the book will be strongly recommended to them, in order to encourage the sales". ${ }^{37}$

With the strong competition in the book market and the developments in the offices of the Ministry, it becomes clear how much the success of Orfila's book was due to the social (and musical) skills he displayed at Princesse de Vaudémont's soirées. Thanks to his powerful contacts, it seems that Orfila managed to make arrangements with other members of the French government. Just four days after the publication, his future English translator, William Price, wrote that "upwards of 3,000" copies had been sold "at 3 francs each ... more than one half of which have been taken by the Ministries of the Police, of the Interior and of the Marine for distribution in their departments". And he added that "such a protection could hardly be expected I suppose in England". 38 Thanks in part to this protection, four editions were published in France between 1818 and 1830. This success had a strong bearing on the work's international diffusion but, as will be discussed in the last section, Orfila also provided active support for the international circulation of his book. Many German, Italian, Spanish, English, Portuguese and Danish translations were published soon after the first edition (see appendix). ${ }^{39}$ Orfila's fame as a toxicologist (and singer) was crucial in the success of the book; however, to explain the large number of editions and translations, attention should now be turned to the book's intended audience.

\section{Addressing Lay Audiences}

The discussion on the origins of Orfila's book in the previous section has provided some clues regarding the intended readership. The book was written for all those who might be involved in cases of criminal and accidental poisoning: physicians (either acting as courtroom experts, or providing care to a patient), magistrates (who had to be able to understand experts' reports), and lay people who might have to provide immediate first aid in cases of accidental poisoning. In his introduction, Orfila noted that his book was aimed not only at "physicians, surgeons, officiers de santé and apothecaries" but also at other persons who might have to give immediate relief in the absence of the physician:

It is also of the highest importance that mayors, clergymen, the heads of establishments, and of families, and the inhabitants of the country, should know all the resources of art in this respect,

\footnotetext{
${ }^{36}$ ANF, F8/161 [Draft note, s.d.]: "M. Chaussier a récemment composé un petit traité sur les empoisonnemens, et qu'on nous avoit annoncé qu'il était dans l'intuition de demander la même faveur que M. Orfila."

${ }^{37}$ ANF, F8, F8/161. (The draft version was written $c .3$ June 1818.) Orfila also attempted to obtain similar support for his book on legal medicine published in 1821. See ANF, F8/161. See also
}

Wellcome Library, London, MS. 7375/235, in which Orfila attempted to obtain additional funding for his publications on toxicology with the support of $\mathrm{M}$ Lefaivre, royal physician.

${ }^{38}$ Wellcome Library, Ms 7375/217, Letter from William Price to William Phillips, Paris, 6 June 1818

${ }^{39}$ A bibliography of the various translations can be accessed at: http://www.bium.univ-paris5.fr/ histmed/medica/orfila.htm. 


\section{José Ramón Bertomeu-Sánchez}

in order to give immediate relief to the unhappy victims of these accidents, when the practitioner is at a distance, and cannot arrive until some hours after the occurrence. ${ }^{40}$

In many passages in the first edition, Orfila explained that the book had been adapted for use by his intended lay audience. His manual, he said, was "free from scientific terms, as being often more difficult of comprehension by such as are unacquainted with medicine than the subject itself". He added that "wishing to adapt it to the capacities of all [le mettre à la portée de tout le monde], [he had] deliberately omitted everything relative to theory and to the examination of dead bodies". He explained that he had "scrupulously described" the methods of preparing remedies, the doses and time of administration aiming to render it "more intelligible" to his "readers who possess no knowledge of medicine". ${ }^{41}$ Reviews made by physicians also noted the importance of the lay audience. Nathaniel Potter, an American physician who wrote a thesis on the properties of arsenic, stated that the book was an "abridgment of ORFILA's celebrated work ON POISONS", "rendering it cheaper and more portable, hence more extensively useful". And he added that:

Such a work is one of the greatest desiderata of practical medicine, and should be in the hands, not only of every physician, but every master of a family whose situation does not permit him to command immediate medical aid. The proper antidote, or best method of obviating the effects of all known poisons, whether vegetable, mineral or animal, are accurately described, and the method of exhibiting them distinctly expressed, divested of much technical term[inology] [which] might embarrass the unlearned. It is almost the only work intended for popular use that can be adapted to general comprehension. I believe but one sentiment prevails among the faculty, as to the merits of the Work. ${ }^{42}$

In spite of these positive comments, there are many indications that Orfila was not convinced of the usefulness of writing for a lay audience. In fact, he seems to have changed his mind on the matter in the years that followed the publication of the first edition, as he made significant changes in the introduction to the next three editions. Though some parts of the introduction remained almost intact, the previously quoted references to lay readers were progressively removed from the book. In the second edition (1821), Orfila deleted the sentence quoted in which he defended the absence of scientific terminology and theory in order to adapt his book to "the capacities of all" but he retained the reference to "mayors, clergymen, the heads of establishments, and of families, and the inhabitants of the country" as part of the intended audience mentioned in the first paragraphs of the introduction. In the third edition (1825), however, these references were

\footnotetext{
${ }^{40}$ Orfila, 1818, translation Orfila/Price, Introduction, p. i. A similar intended audience is mentioned by Chaussier, op. cit., note 34 above, pp. 7-11.

${ }^{41}$ Orfila, 1818, pp. xii-xiv: “ ... nous l'avons débarrassé des termes scientifiques, souvent plus difficiles à comprendre pour les personnes étrangères à la médecine que le fond de la matière; désirant le mettre à la portée de tout le monde, nous avons omis à dessein tout ce qui est relatif aux théories et aux ouvertures des cadavres.... Nous avons scrupuleusement décrit la manière d'administrer et de
}

préparer les médicamens, et nous avons indiqué leurs doses et l'époque à laquelle ils doivent être donnés.... nous sommes persuadés que ceux de nos lecteurs qui ne possèdent aucune connaissance en médecine ne nous blâmeront pas l'avoir indiqué, avec un peu plus de détail tout ce qui est relatif au traitement, afin de le rendre plus intelligible."

${ }^{42}$ Potter's review was published in Orfila/Black, 1819 , Baltimore, title-page. The book mentioned is $\mathrm{N}$ Potter, An essay on the medicinal properties and deleterious qualities of arsenic, Philadelphia, printed by William W Woodward, 1796. 


\section{A Popular Treatise on Poisons by Mateu Orfila (1818)}

removed entirely, and they did not reappear in the fourth and last edition (1830). These changes reflect tensions that will be discussed below. In the meantime, it is worth noting that some parts of the book were clearly addressed to physicians (for example, the sections describing medical instruments and treatments) and would be largely incomprehensible to lay people. Moreover, in many places, Orfila clearly stated that the role of lay people was merely to give "immediate relief to the unhappy victims" when the "practitioner" [praticien] was absent. ${ }^{43}$ Orfila pointed out the risks inherent in the use of medication or when attempting cures without the necessary supervision of a doctor; only physicians could be trusted to take decisions in certain cases. For instance, after dealing with asphyxia, Orfila described several signs which were used to distinguish real from apparent death and mentioned several cases in which some of these signs had been reported but the person had not in fact died. Orfila warned that "not one of the enumerated signs, taken separately (except well-characterized putrefaction)" was "sufficient to prove that a person is dead". Only physicians (and not lay people) could decide in these cases:

The most certain sign of death, is distinct putrefaction; but is it prudent to wait until it is well developed before the interment? This practice is dangerous to attendants, and ought to be forbidden. It has been thought that a commencement of putrefaction was sufficient to prove that the individual was dead, and that the interment should take place immediately after this sign. We join in this opinion; but at the same time, we must insist that it does not belong to the vulgar to decide whether there is or is not a commencement of putrefaction; a physician only can ascertain this fact. How many times have we seen persons who were thought dead, exhaling a bad odour, exhibiting several violet spots upon the skin, and other signs of putrefaction, recover in the space of a few hours by means of appropriate relief ${ }^{44}$

The quotation and the changes in the intended audience show that "boundary work", that is, marking the limits between the expert and lay sphere in medicine, was an important issue in Orfila's book. By offering guidelines for first aid to lay people, Orfila did not intend to transform them into expert doctors. Decisions concerning therapeutic practice should be left in the hands of physicians. Like many other (though not all) nineteenthcentury medical popularizers, he thought that it was hardly possible for lay audiences to gain a sufficient understanding of medical theory and practice to follow the therapeutic precepts of popularizing works without any risk. The idea is clearly expressed in another contemporary popular book on poisons and first aid, written by Félix CadetGassicourt. In the introduction, Cadet-Gassicourt strongly criticized the "soi-disant Médecine à la portée de tous" (the so-called medicine within the reach of all) arguing that "far from encouraging the wrong and pernicious thought that it is ever completely safe for lay people [gens $d u$ monde] to treat themselves, he would rather wish to contribute to convince a portion of the public ... that it is a real game of chance, in which everyone's stake is their health, where the chance of final benefits, as is known, is hardly on the players' side". 45

${ }^{43}$ Orfila/Price, 1818 , p. i.

${ }^{44}$ Orfila, 1818, pp. 189-90, translation Orfila/ Price, 1818 , p. 151. See also Orfila, 1818, pp. 189-94, emphasis by Orfila (and the translator).

\footnotetext{
45 "Loin d'encourager la fausse et pernicieuse pensée qu'il y ait jamais sécurité complète pour des gens du monde à se traiter eux-mêmes, il souhaiterait bien plutôt de contribuer à convaincre la portion
} 


\section{José Ramón Bertomeu-Sánchez}

From this point of view, the role of popular works was to describe only preventive measures, guidelines for providing first aid, and to offer warnings against unqualified healers, dangerous popular practices and superstitions. In his book, Orfila criticized not only popular ideas on poisons and antidotes, but also the practices of quacks. He also warned against "the dangers" of using certain medicines "without consulting the doctor" and the hazards of "self-administration". For example, mercurial drugs could be heroic remedies in the hands of a "skilful physician" [médecin habile] but "as ignorant persons [charlatans] often sport with popular credulity, and administer them without precaution, it is important to mark the dangers to which patients are exposed". "Some other substances "too often employed by quacks" were described by Orfila as poisons. ${ }^{47}$ In other cases, Orfila's critical remarks were aimed at popular customs. He also warned against dangerous everyday practices, for instance, the use of copper or lead kitchen utensils, or the possible confusion between different plants, or mineral substances such as nitre, barite, and Glauber's salt. ${ }^{48}$ More warnings and criticisms appeared in the chapters on food and adulteration. Orfila described the risks of using substances such as lead compounds with wine, syrups or brandies. He also criticized some fallacious tests for detecting possible adulteration. ${ }^{49}$

In this respect, Orfila's book (like many other nineteenth-century popular books on science) contains a wealth of information on popular remedies, healing practices and "everyday technology" which have all but disappeared, leaving hardly any other written records or other traces that might permit their study. His comments and criticisms offer clues to the importance of the role of unqualified healers and popular medical practices in French rural communities at the beginning of the nineteenth century. ${ }^{50}$ Orfila was probably well aware of the difficulties of popularizing modern toxicology in that context.

nombreuse du public, dont le faible est connu pour la soi-disant Médecine à la portée de tous, que c'est un véritable jeu de hasard, où la mise de chacun est la santé, où la chance définitive des profits, comme on sait, n'est guère du côté des joueurs". F CadetGassicourt (1789-1861), Premiers secours avant l'arrivée du médecin, Paris, Labé, 1845, pp. viii-ix. An American review of Orfila's book affirmed: "we are not favorably disposed towards popular works on the healing art in general, but in the present case, the accidents occur so often under circumstances precluding the reach of professional aid within a short time, and time is so valuable in all instances of poisoning, that we are disposed to diffuse, as much as possible, by popular works, an acquaintance with the elements of toxicology". The Southern Review, 1831, 7: 297-319, p. 313. See similar views defended by the Italian physician Paolo Mantegazza, studied by P Govoni, Un pubblico per la scienza. La divulgazione scientifica nell' Italia in formazione, Roma, Carocci Editore, 2002, pp. 207-70. A very different view was supported by François V Raspail, whose antagonism toward Orfila was certainly not limited to the forms of popularization. See J Poirier and C Langlois, Raspail et la vulgarisation médicale, Paris, Sciences en Situation, 1992.
${ }^{46}$ Orfila, 1818 , p. 22 , translation Orfila/Price, 1818, p. 24.

${ }^{47}$ Orfila, 1818, p. 77. See, for instance, "la sabine, trop souvent maniée par les charlatans, est trèscaustique et peut déterminer la mort" (p. 80). "Coloquinte, le vin de coloquinte et les autres préparations de ce genre, dont les charlatans font un si grand usage, et à l'aide desquelles ils prétendent guérir une foule de maladies, doivent être prises avec prudence et par ordre d'un médecin; car elles peuvent devenir funestes et occasionner la mort, étant introduites dans l'estomac, données sous forme de lavement, ou appliquées sur la peau" (p. 77).

${ }^{48}$ Orfila, 1818 , pp. 32-4, 63-5; 44, 48-51. See also his critical remarks on the popular uses of "Spanish flies" (cantharides), cf. Orfila, 1818, p. 58, and Orfila/Price, 1818, p. 51.

${ }^{49}$ Orfila, 1818 , pp. 61-5 and pp. 200-4.

${ }^{50}$ See M Ramsey, Professional and popular medicine in France, 1770-1830: the social world of medical practice, Cambridge University Press, 1988, and $\mathrm{J}$ Leonard, La Médécine entre les savoirs et les pouvoirs: histoire intellectuelle et politique de la médecine française au XIXe siècle, Paris, AubierMontaigne, 1981, pp. 68-95. 


\section{A Popular Treatise on Poisons by Mateu Orfila (1818)}

The problem of terminology is a case in point. Popular knowledge of poisons included not only antidotes but a rich nomenclature for poisonous minerals, plants and animals. But the terms used were quite different from the scientific ones and were often limited to specific local areas; their translation into scientific terms was a difficult task. Moreover, two major linguistic changes took place in the eighteenth-century: Carl von Linné's reform of botanical names, and the new chemical nomenclature devised by Antoine Lavoisier, Louis Guyton de Morveau, Antoine-François Fourcroy and Claude-Louis Berthollet. As Orfila said, the new scientific terms could be "more difficult of comprehension by such as are unacquainted with medicine than the subject itself", 51 and in fact the reforms introduced new names that were strange not only to lay people but also to many physicians and apothecaries. ${ }^{52}$ French apothecaries were reluctant to adopt the new terms because they were based on chemical compositions, whereas the old terms referred to medical properties or physical appearance (colour, consistency, etc.) which were better suited to their work. Names such as saffron of Mars, emetic or blue vitriol were much more familiar to nineteenth-century lay audiences than the new ones, "carbonat of iron", "tartrite of potash antimoniated" and "sulphat of copper". 53 To overcome this problem, Orfila included many tables with the correspondences between popular, old and new scientific terms. They were intended not only for lay audiences but also for many of his colleagues (physicians and apothecaries) who had great difficulty in understanding the new chemical terminology.

Orfila's concern with terminology highlights not only the existence of a body of popular knowledge on poisons, but also the importance of translation in nineteenth-century toxicology. As toxicology was a field in which a variety of professional and social groups were involved-physicians, apothecaries, chemists, and so on-translation was necessary to exchange information, practices and material culture across borders. Equally, as toxicologists were also compelled to address lay people in the courtrooms, they had to adapt their esoteric knowledge to a discourse that would be comprehensible to judges, magistrates and juries. They came up against this problem once more when they attempted to give first-aid guidelines to lay audiences. But most of their communicative practices were accompanied by "boundary work", that is, legitimating the area of the experts and identifying the border between expert and lay knowledge. While enlightening lay audiences, Orfila also wanted to maintain the realm of medical practice under the control of the medical community. ${ }^{54}$ Thanks to his textbooks and his social and political network, Orfila managed to carve out a career as a toxicologist in which chemical analysis and animal experimentation played a major role. In this context, just a handful of physicians and pharmacists, who had access to laboratory resources, could meet the

\footnotetext{
${ }^{51}$ Orfila, 1818, pp. xii-xiii; translation Orfila/Price, 1818, p. ii.

${ }^{52} \mathrm{~A}$ German reviewer praised the translator for having included many old names. See Allgemeines Repertorium der Literatur, 1831, 3: 267-9.

${ }^{53}$ The names are taken from Method of chymical nomenclature, transl. James St John, London, 1788. An online version of some parts of this text is published at http://web.lemoyne.edu/ giunta/ nomenclature.html (accessed 21 Jan. 2009). See B
}

Bensaude-Vincent and F Abbri (eds), Lavoisier in European context: negotiating a new language for chemistry, Canton, Science History Publications/ USA, 1995.

${ }^{54}$ On "the double-edged nature of medical discourse both elusive and accessible", see R Harris, Murders and madness: medicine, law and society in the fin de siècle, Oxford, Clarendon Press, 1989, ch. 2, pp. 24-79. 


\section{José Ramón Bertomeu-Sánchez}

standards required by Orfila to produce reliable toxicological knowledge. But this disciplinary agenda and its associated boundary work was challenged by the controversies on animal experimentation, to be discussed in the next section.

\section{Antidotes for Expert Controversies}

Orfila's book contained chapters on all the groups of important poisons. Each chapter included a description of "the effects produced by several poisons and various accidents, the means of knowing the presence of these poisons, and the nature of these accidents; and the remedies necessary for preventing and counteracting the injuries and diseases, to which they may give rise". ${ }^{55}$ Orfila classified poisons in four categories: irritating (causing inflammation of the parts to which they are applied), narcotic, narcotic-acrid, and septic or putrefactive. ${ }^{56}$ Each class included many groups (concentrated acids, arsenic and its compounds, copper salts) and species. Orfila offered a brief description of the symptoms of each poison, its main antidotes, how to treat cases of poisoning (listing the medicines, doses, the order in which they should be taken, and so on) and guidelines for recognizing the different poisons and distinguishing them from other substances (for instance, in the case of mineral poisons, by using selective chemical tests). The last part of the book included a discussion on cases of asphyxia (by drowning, hanging, or by inhaling certain vapours), with a special section on apparent death. After a brief section on burns, Orfila ended the book with a chapter on adulterated wines: he outlined the various fraudulent methods used to improve their strength, or change their odour or colour and ways of detecting them (mostly by chemical tests).

As already noted, the book contains a great deal of sanguine criticism of popular health practices and quackery. But in many other cases Orfila's criticism was aimed at physicians, surgeons, and pharmacists who used drugs which he regarded as useless or even dangerous. For instance, he argued against the use of some arsenical preparations such as "the paste of Rousselot" (a powder which was applied externally) because it "may cause all the symptoms of poisoning". Orfila remarked that arsenic compounds do not kill, "as is vulgarly believed, because they burn the stomach and intestines, but because they are absorbed and destroy the vital properties of the heart". Taking "these facts" into account, Orfila wondered why "some physicians" administered arsenic in the cure of certain diseases, taking the risk of "disposing the patient afterwards to a disease of the heart". ${ }^{57} \mathrm{He}$ also warned against several dangerous substances that were not recognized as poisons by physicians: nitre, liver of sulphur and even barite, when given in too large a dose. ${ }^{58}$

But the most controversial part of Orfila's book was the section on antidotes. Swift administration of the right antidote was crucial to the survival of the victim. Because most antidotes were only really effective if administered very soon, they usually had

\footnotetext{
${ }^{55}$ Orfila/Stevenson, 1826, pp. I-II (translator's preface).

${ }^{56}$ On classification of poisons, see Wahrig, op. cit., note 1 above.

${ }^{57}$ Orfila, 1818 , pp. $26-8$, translation Orfila/Price, 1818 , pp. $28-9$. See also his experiments and clinical
}

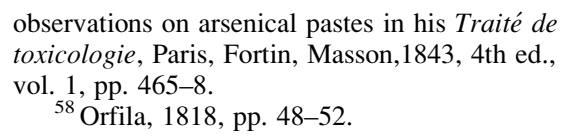
toxicologie, Paris, Fortin, Masson,1843, 4th ed. vol. 1 , pp. 465-8.

${ }^{58}$ Orfila, 1818 , pp. $48-52$. 


\section{A Popular Treatise on Poisons by Mateu Orfila (1818)}

to be applied by the victims themselves or by their relatives or friends, that is, by lay people who needed precise instructions concerning the quantities required, the procedure, and the effects. But there was no general agreement among the French medical community on the antidotes that should be used for each poison, their effectiveness, and the correct doses. Therefore, when proposing his own antidotes, Orfila was obliged to challenge many of the suggestions put forward by his medical colleagues:

Before speaking of the treatment of poisoned persons, we shall examine, under the title of Counterpoisons, those substances which have been regarded as such by several physicians: we shall reject such as are useless or dangerous, and recommend only those the efficacy of which has been demonstrated by reiterated experiments. ${ }^{59}$

Orfila provided many examples of "useless or dangerous" antidotes in his chapters on arsenic, lead, and vegetable poisons, and he suggested new (or old) ones whose effectiveness, he claimed, had been proved "by "numerous and incontestable experiments". ${ }^{60} \mathrm{He}$ criticized the antidotes for corrosive sublimate proposed by Pierre Toussaint Narvier in a very influential book on poisons. ${ }^{61}$ Orfila remarked that Narvier's antidotes had been tested only in the chemical laboratory, not by means of animal experiments. When he applied Narvier's antidotes to poisoned dogs the animals died; so he concluded that Navier's antidotes were "entirely useless when dealing with a poisoning with liquid corrosive sublimate". ${ }^{62}$ He followed the same procedure for many poisons and their antidotes. The experiments were not described in the abridged book, but Orfila summarized his main conclusions and introduced them with sentences such as "our experiments prove that the best counter-poison for acids is ..." or "it has been proved, by positive experiments, that ...".63

We shall see that Orfila's experiments on poisons and antidotes were not in fact as "positive" and "incontestable" as he claimed. Indeed, animal experiments and their use in medicine was a controversial issue in Orfila's time. ${ }^{64}$ In 1817 , just one year before the publication of Orfila's Secours, another physician, Charles-Alexandre-HippolyteAmable Bertrand, advocated the use of charcoal powder as an antidote to many poisons, criticizing the views defended by Orfila in his famous Traité. Quoting other publications, Bertrand challenged the reliability of Orfila's experiments with recourse to two arguments that were often used against animal experimentation: the differences between

\footnotetext{
${ }^{59}$ Ibid., pp. xvi-xvii, translation Orfila/Price, 1818, p. iv.

${ }^{60}$ Orfila, 1818 , pp. $29,63-5,83$.

${ }^{61}$ Pierre-Toussaint Navier, Contre-poisons de l'arsenic, du sublimé corrosif, du verd-de-gris et du plomb, Paris, Widow and Son of Méquignon \& Didot, Jnr, 1777. On Navier, see G Dalmasso, 'Presence de la "chymie" dans la France du Nord, de la deuxième moitié du XVIIIè siècle au premier tiers du XIXè', Lille, doctoral thesis, 2003.

${ }^{62}$ M Orfila, Traité des poisons, Paris, Cuchet, 1814-1815, vol. 1, pp. 91-4. He affirmed: "Le médecin de Châlons [Navier] tire ses conclusions d'après des faits purement chimiques; les miennes
}

découlent d'une multitude d'expériences faites sur les animaux vivans" (pp. 90-1). For a similarly critical view of Navier's antidotes, see C Renault, Nouvelles expériences sur les contre-poisons de l'arsenic, Paris, Croullebois, 1801(an IX). He also performed experiments on poisoned dogs.

${ }^{63}$ Orfila, 1818 , pp. 7, 17, translation Orfila/Price, 1818, pp. 13, 20.

${ }^{64}$ See N Rupke (ed.), Vivisection in historical perspective, London and New York, Croom Helm, 1987. For a broad discussion, see A Guerrini, Experimenting with humans and animals: from Galen to animal rights, Baltimore, Johns Hopkins University Press, 2003. 


\section{José Ramón Bertomeu-Sánchez}

animal and human physiology and the effects of the ligature of the oesophagus, the method used by Orfila to prevent the animal from vomiting the poison. ${ }^{65}$

The major attack on Orfila's method came from Antoine Portal, an influential representative of the Paris clinical school, who worked in clinical medicine, pathological anatomy and physical diagnosis and, as mentioned above, had also published a popular book on first aid in asphyxias and accidental poisoning. ${ }^{66}$ In July 1818, just a few weeks after the publication of Orfila's book, Portal gave a talk to a group of physicians on "antidotes" and "specific remedies for poisons" and he defended the treatment he suggested in his book, which had been adopted by "all true practising physicians". The success of his treatment-Portal argued-had been proved by "clinical observations on humans who had really been poisoned", not only by "some chemical decompositions and experiments with living animals". After discussing the clinical symptoms and anatomical damage produced by poisons, Portal suggested a general procedure for all the poisons: emetics and purgative enema should be applied if the poison had been swallowed recently, as the main purpose was to expel it. When the effects of the poison became evident, Portal recommended abundant "relaxant" and "anodyne" drinks (aiming to reduce the "activity of the poison") and, finally, a bath, bleeding and vesicatories. Portal preferred this treatment to the allegedly specific antidotes because the efficacy of the latter substances had been proved only in animal experiments or in chemical test-tubes, not in humans - and that, as a result, they might be useless or even potentially harmful. Portal doubted that data based on chemical analysis and animal experimentation were reliable enough to justify the introduction of new antidotes for poisons and the replacement of old, well-tested general treatments. ${ }^{67}$ In fact, like other

\footnotetext{
${ }^{65} \mathrm{C}$ A H A Bertrand, Manuel médico-légal des poisons introduits dans l'estomac, et des moyens thérapeutiques qui leur conviennent, Paris, Croullebois, 1817, particularly pp. vii-x, 200-3 (ftn) See also the critical review of this book in Nouveau Journal de Médecine, 1818, 2: 133-47. On Bertrand, see M Fabre, 'Notice nécrologique de M. le docteur Bertrand', Annales Scientifiques, Littéraires et Industrielles de l'Auvergne, 1849, 29: 357-69. The potentially different effects of poisonous substances in animal and human beings as well as the misleading effects of manipulations in beasts (violence, tying, ligature of the oesophagus) were mentioned by other critics of Orfila in the following years. See

J R Bertomeu-Sánchez, 'Sense and sensitivity: Mateu Orfila, the Marsh test and the Lafarge affair', in Bertomeu and Nieto-Galan (eds), op. cit., note 1 above, pp. 207-42.

${ }^{66}$ See note 33 above. The debate was noticed in the review published in The New-England Medical Review and Journal, 1827, 1: 141-7: "The deserved reputation of this author [Portal] gave his work a wide circulation, and the knowledge of his time was thus extensively and usefully diffused. Orfila's work is much later, and in this circumstance has an advantage, and must be preferred to that of Portal" (p. 143).
}

\footnotetext{
${ }^{67}$ A Portal, 'Quelques considérations sur les antidotes, ou remèdes spécifiques contre les poisons lues au cercle médical, mois de juillet 1818', in idem, Mémoires sur la nature et le traitement de plusieurs maladies, Paris, Bertrand, 1800-1825, vol. 4, pp. 300-16: "Quant au traitement des empoisonnés par des spécifiques, recommandés aujourd'hui par quelques habiles chimistes et par des médecins dont la clinique n'est pas encore bien avancée, presque toujours d'après les seuls résultats de quelques expériences sur des animaux vivants ... à peine peuton citer quelques exemples de leurs succès; tandis qu'il y a une si grande quantité d'heureux traitements par la méthode que je viens d'exposer, que nos livres en sont pleins; succès enfin si nombreux et si remarquables, que les remèdes auxquels on les doit sont devenus usuels dans les villes et dans les campagnes ... Ne pourrait-on pas craindre que la permutation des poisons, en un agrégat non nuisible, ne se fit pas dans l'estomac, agité par de vives convulsions, aussi parfaitement et aussi vite qu'elle pourrait se faire dans un récipient maintenu en un repos parfait? Il faudrait à cet égard des résultats bien positifs pour croire autrement" (p. 315).
} 


\section{A Popular Treatise on Poisons by Mateu Orfila (1818)}

physicians, Portal doubted the existence of specific antidotes for each poison and preferred the general treatment. ${ }^{68}$

In the second edition of Secours, Orfila acknowledged that some of the antidotes in question had been introduced only very recently, and that he himself had been responsible for their introduction. He affirmed that some physicians had rejected them out of hand, "before having any knowledge of them" while "many French and foreign physicians have verified in human beings that the results of our experiments were accurate". 69 Reacting to Portal's attack, Orfila inserted a new chapter in his second edition in which he defended chemical analysis and animal experimentation as a valuable source of knowledge for toxicology and therapeutics:

Can one seriously say that the results of experiments with antidotes are worthless because they have been tested on animals alone? We do not think so; indeed, place lead acetate in a glass, a pot, the stomach of a dog or a man; then, pour over it soda sulphate (the antidote to lead salt) and, as soon as it comes into contact, the poison will be decomposed, the antidote will have produced all the expected effects; substitute the lead acetate with salts of mercury, or salts of copper, and the soda sulphate with albumin, and a similar effect will be found. Would we not be surprised, then, to hear that the decomposition of the poison by the antidote takes place in the stomach of a dog and not in the stomach of a man?; it is as if we said: it is just because poison and antidote are mixed inside the human stomach that their reciprocal chemical action ceases; this decomposition is independent of the recipient in which it takes place; provided that poison and antidote are in contact, the nature of the recipient that contains the mixture is of no importance. Note that the doctor who speaks this language, will not hesitate to employ burned magnesia [magnesia calcinée], when he suspects the presence of an excessive quantity of acid in the stomach; in that case, he accepts that the magnesia seizes the acid in the stomach, as it would do in an inert recipient. ${ }^{70}$

Orfila developed his claim by clarifying his idea of antidote or counterpoison, that is, a substance capable of "decomposing the poison, or of combining with it at a temperature equal or inferior to that of the human body" and "forming a new product which does not exert any harmful action on the animal economy". ${ }^{71}$ An antidote, then, must be able to

\footnotetext{
${ }^{68}$ For similar views, see E Montmahou, Manuel médico-légal des poisons, ... rédigé sous les yeux du Professeur Chaussier, Paris, Compère jeune, 1824.

${ }^{69}$ Orfila, 1821, pp. 8-9: "plusieurs médecins français et étrangers se sont empressés de vérifier chez l'homme, que les résultats de nos expériences étaient exacts".

${ }^{70}$ Ibid., pp. 9-10: "Parle-t-on sérieusement lorsque pour annuler des résultats relatifs aux expériences faites sur les contrepoisons, on dit qu'elles ont été tentées sur des animaux seulement? Nous ne le pensons pas; en effet, que l'on introduise de l'acétate de plomb dans un verre, dans un pot, dans l'estomac d'un chien ou d'un homme; que l'on verse par-dessus du sulfate de soude (contre-poison du sel de plomb) aussitôt qu'il aura contact, le poison sera décomposé, le contre-poison aura produit tout l'effet que l'on en attendait: que l'on substitue à l'acétate de plomb, les sels de mercure, de cuivre, et au sulfate de soude de l'albumine, on obtiendra des effets analogues. N'a-t-on pas lieu de s'étonner maintenant,
}

lorsqu'on entend dire que la décomposition du poison par le contrepoison, a lieu dans l'estomac d'un chien tandis qu'elle ne se fait pas chez l'homme; c'est comme si on disait: par cela seul, que le poison et le contre-poison sont mélés dans l'estomac de l'homme, l'action chimique de l'un sur l'autre cesse; cette décomposition est indépendante du vase dans lequel elle s'opère; pourvu que le contact ait eu lieu entre le poison et le contre-poison, peu importe que la nature du vase qui contenait le mélange. Notez que le même médecin qui tiendra ce langage, n'hésitera pas à administrer de la magnésie calcinée, lorsqu'il soupçonnera la présence d'une trop grande quantité d'acide dans l'estomac, dans ce cas, il admettra que la magnésie s'empare de l'acide dans l'estomac, comme elle le ferait dans un vase inerte." Also in Orfila, 1825 , pp. 9-10, Orfila's emphasis. The translation is mine- the text was not included in the American edition of 1826 .

${ }^{71}$ Orfila, 1821, p. 13: “des substances susceptibles de décomposer les poisons liquides ou solides, ou de 


\section{José Ramón Bertomeu-Sánchez}

react chemically with the poison; this essential characteristic can be studied by means of chemical tests and animal experimentation (this would have been much more difficult to defend if he had adopted a different definition of antidote). ${ }^{72}$

The controversies on animal experimentation were related to the new image of expert toxicologists (a select medical elite of specialists) which Orfila was gradually moulding with his publications and research. His new experimental protocols required a high degree of competence that was usually beyond the scope of local physicians and pharmacists who had been traditionally requested to act as expert witnesses in poisoning trials. In contrast, Parisian experts had laboratory facilities for animal experimentation and cadavers for autopsies, and so the new toxicological methods clearly favoured the role of the Parisian medical elite over local physicians and pharmacists in courtrooms. In this context it is no surprise that controversies on the role of experiments in toxicology reached the courtrooms. The Italian physician Francesco Rognetta, who confronted Orfila during a famous poisoning trial, ironically affirmed that it was "quite probable that the laboratories of nature were particularly different from Orfila's laboratory". 73 Discussing the influence of arsenical soils, François-Vincent Raspail rejected Orfila's experiments because they could not "imitate the procedures of nature". ${ }^{74} \mathrm{He}$ stressed his point with some sharp remarks contrasting the "purely theoretical experiments" performed in the "cabinet", with the nature of forensic practice, in which the products at stake were never simple chemical substances but complex mixtures of organic and inorganic compounds, and whose results were not just new theoretical interpretations but criminal evidence that could be decisive to the "life or death" of the accused. ${ }^{75}$ Despite Raspail's persuasive rhetoric, the debate never really centred on the desirability of experimentation, but on the spectrum of its legitimate uses in toxicology. In fact, since his very first publications on toxicology, Orfila had always pointed out the differences between the conditions of the laboratory and those of real life. For instance, in a paper dealing with lead poisoning, he pointed out the "modifications imprinted by life in the poisoning compounds that are formed in the stomach and intestines", so toxicological knowledge has to be based on "experiments performed on living animals". ${ }^{76}$ However,

se combiner avec eux à une température égale ou inférieure à celle de l'homme, de telle manière que le nouveau produit formé n'exerce aucune action délétère sur l'économie animale ... Ces substances doivent pouvoir être prises à grande dose sans danger; leur action doit être prompte et indépendante des sucs gastrique, muqueux, bilieux, etc. que l'estomac peut contenir."

${ }^{72}$ Orfila, 1825 , p. 14 . He criticized other physicians who regarded antidotes as "des médicamens incapables de décomposer les substances vénéneuses, ou de se combiner avec elles de manière à les neutraliser, et qui pourtant diminuent les effets auxquels elles ont donné lieu; calment les accidents de la maladie, et peuvent même la faire disparaître; tels sont, par exemple, les liquides adoucissants que l'on emploie avec succès dans le traitement de la phlegmasie, qui est le résultat de l'introduction d'un poison dans l'estomac."

\footnotetext{
${ }^{73}$ F Rognetta, Nouvelle méthode de traitement de l'empoisonnement par l'arsenic, et documents médico-légaux sur cet empoisonnement; ... suivis de la déposition de M. Raspail devant la cour d'assises de Dijon, Paris, Gardenbas, 1840, p. 26.

${ }^{74}$ Ibid., pp. 83-6. See also similar arguments by F Rognetta, ibid., pp. 25-7.

${ }^{75}$ Gazette des Tribunaux, 2-3 Dec., 1839, pp. 106-7: "Si la science ... doit être timide et craintive lorsqu'elle fait dans le cabinet des expériences purement théoriques, combien ne doitelle pas trembler lorsqu'elle parait devant la justice! combien doit-elle craindre de porter une affirmation, quand il s'agit de la mort ou de la vie de deux individus!"

${ }^{76}$ M Orfila, 'Mémoire sur l'empoisonnement par les sels de plomb', Annales d' Hygiène Publique et de Médecine Légale, 1839, 21 (1): 149-68, p. 161: "La solution de ce problème est hérissée, messieurs,
} 


\section{A Popular Treatise on Poisons by Mateu Orfila (1818)}

as noted above, his critics remarked that animal experimentation placed animals in unnatural conditions (extreme pain, oesophagus ligature, etc.) that could produce inconclusive experimental results. ${ }^{77}$ The following section shows how this debate shaped the way in which Orfila's book was appropriated outside France, thanks to the active role of the translators.

\section{Traduttori, Traditori}

Apart from the first edition, between 1818 and 1819 several translations of Orfila's book were published in other European countries (see the table at the end of this paper). These consisted of two English editions (including two American reprints), three German translations (one of them published in Hungary), ${ }^{78}$ four Italian, one Danish and one Spanish. In 1820, a new version of R H Black's English translation became available. Other translations appeared in the following years, some of them, like the Portuguese edition and the second Spanish edition, published in Paris- the last of these by the "Hispanic-French Bookseller Rosa", which produced many Spanish translations of French books during that period. ${ }^{79}$ Based on Orfila's book, two editions of a teaching chart ( 1 sheet. $67 \times 16 \mathrm{~cm}$ ) entitled 'What to do in cases of poisoning' were published in London, including "the most simple and comprehensible" instructions "within the reach of all degrees of capacity". ${ }^{80}$

The swift publication of the translations (some of which came out in the same year as the first edition) can hardly be attributed to the fame of Orfila. Many other authors, like those mentioned in the first section, published similar books but did not reach such a large international audience in such a brief period of time. There are several clues that suggest that Orfila actively contributed to this process. We know that he sent his book to several English booksellers and editors just a few days after the publication of the French edition. At the beginning of June 1818, Orfila told one of his first translators, William Price, that "he had written to two or three booksellers in London offering to sell them the manuscript". On the same day Price contacted another London bookseller, the mineralogist William Phillips (1775-1828), and offered him his own translation, which had been done "under the auspices of the author who understands English very well". And, what was more, the author was willing to "read over the translation". Price affirmed that "about a fourth" of the book was already translated into English and he

d'énormes difficultés; car il ne s'agit pas seulement d'étudier un fait chimique, tel qu'il se produirait dans des vases inertes; nous ne pouvons pas ici faire abstraction des modifications imprimées par la vie aux composés vénéneux qui se forment dans l'estomac et dans les intestins des personnes empoisonnées, et nous sommes obligés, pour obtenir un résultat quelconque, de baser notre travail sur des expériences faites sur les animaux vivans." On Orfila's ideas about vitalism and "chimisme", see J R Bertomeu Sánchez and A García Belmar, 'Mateu Orfila's Eléments de chimie médicale and the debate about chemistry applied to medicine during the early XIXth century in France', Ambix, 2000, 47: 1-28.

\footnotetext{
${ }^{77}$ See, for instance, Gazette des Hôpitaux, 29 Aug. 1839, p. 102. The oesophagus ligature was specially criticized by the Italian doctors G Giacomini and F Rognetta.

${ }^{78}$ The extraordinary number of German translations published within a few months of the first edition was remarked on by one of the reviewers. See Allgemeines Repertorium der Literatur, 1831, 3: 267-9, pp. 267-8.

${ }^{79}$ Orfila, 1824 , p. 189 . The publisher's actual name was: "Librería Hispano-Francesa de Rosa".

${ }^{80}$ The Chemist, 1843, 4: 239.
} 


\section{José Ramón Bertomeu-Sánchez}

undertook to complete the translation "by the $20^{\text {th }}$ or at the farthest by the $25^{\text {th }}$ " June. He urged the editor to "perceive the importance of losing no time at least in announcing the work, and if possible of securing the copyright" and he suggested several possible "pecuniary arrangements-further evidence that the publication was perceived as a potential source of profit for translators and editors. ${ }^{81}$ Finally, the book was published in London some months later; on the title-page it stated that the translation had been carried out "under the inspection of the author". ${ }^{2}$ Price's worries about other possible competitors proved well founded: another English translation was published at almost the same time by the surgeon Richard Harrison Black. ${ }^{83}$

Like Price, many other first translators may have been in contact in some way with Orfila. The Italian translator, Carlo Porta, was a member of the Paris Medical Society who had recently published a paper on poisoning with opium in the Society's journal. ${ }^{84}$ The Portuguese translator, João Fernandes Tavares (1795-1874), was a student of Orfila who had recently defended his medical dissertation at the Paris Faculty. ${ }^{85}$ The case of the Spanish translation of Orfila's Treatise on poisons, which was published in the following year by the Spanish physician Mariano de Larra y Langelot, bears certain similarities. Larra was a political exile living in Paris at that time and he affirmed that he "had the luck to know the author personally" and that the author had promised to revise the translation "word for word". ${ }^{86}$ Jonathan Greely Stevenson (1799-1835) published his English translation in the year he received his medical degree at Harvard (1826). He had been on a study trip to Italy and France in 1824 and 1825, and it may be that he was in contact with Orfila or even attended some of his lectures. ${ }^{87}$ It seems that many of the translators were students or doctors of medicine who had finished their studies a few years after (or just before) the translation. Santiago Grimaud de Velaunde, the Spanish translator of Orfila's book on forensic medicine, was at that time a "student of the Royal School of Medical Surgery" in Madrid. ${ }^{88}$ In the first Spanish translation no translator was mentioned; like his textbook on chemistry, it may have been translated by Orfila himself.

\footnotetext{
${ }^{81}$ Wellcome Library, MS 7375 /217, Letter from William Price to William Phillips, Paris, 6 June 1818

${ }^{82}$ Orfila/Price, 1818. The book was mentioned in a "list of books recently published" in the Eclectic Review, Nov. 1817: 501. A reprint appeared in Philadelphia at the end of the same year. The permission for the American edition was requested in Philadelphia, 22 Oct. 1818.

${ }^{83}$ A London journal included it in a "list of new works published from July 10, 1818, to October 10 , 1818", see British Review, 1818, 12: 541. See Appendix for additional bibliographical data.

${ }^{84}$ Carlo Porta, 'Observations et réflexions sur un empoisonnement par l'opium', Bulletin de la société médicale d'émulation, 1815, 1: 192-203. See also Annali Universali di Medicina, 1819, 10 (29): 183.

${ }^{85}$ Fernandes Tavares was born in Brazil but he read his $\mathrm{PhD}$ in Paris in November 1823, i.e. the year in which he published the translation. In some biographies, he is portrayed as a "great friend" of Orfila. Later on, he became royal physician. He is remembered for having introduced stethoscopes to Brazil. See Antônio da
}

Rocha Almeida, Vultos da Patria, Porto Alegre, Editora Globo, 1961, p. 64; C Araujo, L'Influence française sur la culture brésilenne, Rio de Janeiro, Gráfica Olímpica, 1973, pp. 27-8; and L Santos Filho, História da medicina no Brasil, São Paulo, Editora Brasiliense, 1947, p. 258. I am very grateful to Douglas Carrara (Biblioteca Chico Mendes) for his kind help in translating this biography.

${ }^{86} \mathrm{M}$ Orfila, Tratado de los venenos ... Traducido por el Dr. Mariano de Larra, Madrid, Imprenta de Collado, 1819, p. ix. Larra, who was the father of the famous Spanish writer, collaborated with the Napoleonic government during the Peninsular war, so he was compelled to accompany the retreating troops back to France and he remained there for several years.

${ }^{87} \mathrm{http}: / /$ www.masshist.org/findingaids/doc.cfm?

$\mathrm{fa}=\mathrm{fa} 0151$ (accessed 14 Jan. 2009).

${ }^{88}$ Lecciones de medicina legal y forense... traducidas por "Santiago Grimaud de Velaunde, alumno del Real Colegio de Cirujía [sic] Médica de San Carlos de esta Corte", Madrid, Imprenta Repullés, 1825. 


\section{A Popular Treatise on Poisons by Mateu Orfila (1818)}

Two of the German translators- J A Roschet and Peter Gottlieb Brosse, an apothecarydid not publish any major scientific work, while the other two translators had teaching positions in chemistry or medicine. ${ }^{89}$ It seems that the Danish version was by $\mathrm{C} \mathrm{F}$ Holmer, who worked not directly from the original but from Brosse's German translation. ${ }^{90}$ The author of the German/Hungarian edition (published in German in Pest), János Schuster (1777-1838), had studied law, then medicine, in Pest and travelled to Berlin in 1805, where he met Martin Heinrich Klaproth, one of the most famous chemists in Germany. In 1809, Schuster was appointed professor of natural history, chemistry and botany at the University of Pest, where he also taught legal medicine and pharmacology. He published several papers and books on drugs and chemicals (opium, iodine, iron, and so on) and translated other medical books apart from Orfila's Secours. ${ }^{91}$ The last German translation was published in 1831 by the German physician Johann Friedrich John (1782-1847). John had also studied with Klaproth and became professor of chemistry and pharmacy at Berlin, publishing a great many papers on experimental chemistry (mostly on plant and animal chemistry), several chemistry textbooks and a celebrated volume of tables on plant analyses, which had been translated into French and which Orfila had used. ${ }^{92}$

The ways in which the translators approached their task differed widely. ${ }^{93}$ William Price, whose translation was carried out "under the inspection of the author", produced a version which was quite faithful to the original. Other translators, however, added new chapters, changed sections, revised the terminology, offered additional bibliographic orientation, included new images or added notes that expanded on or criticized the original text. ${ }^{94}$ A reviewer of the three first German translations preferred the translation by Schuster (Pest, 1819) because it included "more useful notes" and added to it was a "Rettungsapotheke", an index of all antidotes, first-aid procedures, remedies and reagents

\footnotetext{
${ }^{89}$ The German translations were critically reviewed in Allgemeine Literatur Zeitung, 1819, 112: 42-8; 113: 50-2. The reviewer recommended Roschet's translation but he was disappointed by the scarce number of additions made by the German translators.

${ }^{90} \mathrm{C}$ Bruun, Biblioteca Danica, Copenhagen, Gyldendal, 1884, p. 793.

${ }^{91}$ A Hirsch, et al., Biographisches Lexikon der hervorragenden Ärzte aller Zeiten und Völker, Berlin, Urban \& Schwarzenberg, 1929-1935, vol. 5, p. 150. See also Á Magyar tudós társaság' (tudományos akadémia) évkönivei, Budan, Öödik Kötet, 1847, pp. 132-58. I am grateful to Gabor Palló for his kind help in translating from the Hungarian. See his paper G Palló, 'Roles and goals of chemical textbooks in the periphery: the Hungarian case', in A Lundgren and B Bensaude-Vincent (eds), Communicating chemistry: textbooks and their audiences, 1789-1939, Canton, Science History Publications/USA, 2000, pp. 367-95

${ }^{92}$ See T L Sourkes, 'Devitalising the elements: Johann Friedrich John (1782-1847) and the liberation
}

of phosphorus and potassium from a vital force', Ambix, 2000, 47 (1): 37-47.

${ }^{93}$ On translation, see N Rupke, 'Translation studies in the history of science: the example of "Vestiges", Br. J. Hist. Sci., 2000, 33: 209-22;

S L Montgomery, Science in translation: movements of knowledge through cultures and time, Chicago and London, University of Chicago Press, 2000; G Petrou, 'Translation studies and the history of science: the Greek textbooks of the 18th century', Science and Education, 2006, 15 (7/8): 823-40.

${ }^{94}$ Orfila/Black, Baltimore, 1819, p. 131. Black added bibliographical information in the chapter on 'Effects of poisonous fish'. He added a note in which he reported that "for farther observations on this subject consult a paper by Dr. Chisholm in the Edinburgh Medical and Surgical Journal for October, 1808." When dealing with "method of introducing air in the lungs", Black included an image of the "laryngeal tube of professor Chaussier" which was used for this purpose (Orfila/Black, 1819, Baltimore, pp. 165-6) 


\section{José Ramón Bertomeu-Sánchez}

to test and recognize the substances. ${ }^{95}$ In some cases, the translators disagreed with Orfila's ideas. The German physician and chemist John introduced a handful of minor criticisms concerning chemicals and reagents (arsenic oxide, reagents for lead, lead-tin alloys) and disagreed with Orfila on the origin of "painter's colic" (a form of lead poisoning). ${ }^{96}$ An anonymous German reviewer criticized many of Orfila's antidotes and treatments. $^{97}$

Some additions were borrowed from similar books on first aid and toxicology. Stevenson added some paragraphs from another French book on poisons ${ }^{98}$ and Black added a special section on "suspended animation and the means of prevention" taken from the Reports of the Royal Humane Society (RHS). ${ }^{99}$ The RHS had been founded in London in 1774 by two doctors, William Hawes and Thomas Cogan. The founders were concerned at the number of people mistaken for dead and, in some cases, buried alive, and they were also interested in methods of reviving the drowned and suffocated; these important topics were both discussed by Orfila in his book. Stevenson quoted the RHS report ${ }^{100}$ but his most important additions were data from chemistry textbooks and materia medica which he had probably used during his studies at Harvard-for instance, John Gorham's chemistry textbook ${ }^{101}$ and Jacob Bigelow's books on materia medica. ${ }^{102}$ The Spanish translation included information from a newspaper, the Gaceta de Madrid. ${ }^{103}$ Black added information from his own clinical experience, clinical histories from other books, and replaced some French prescriptions with simple medicines approved by the London College of Physicians:

In the French school of medicine, numerous prescriptions yet exist, of very antique origin, when the greater the multitude of ingredients, the more sovereign was the effect expected to be produced; but many of those ingredients being uncommon in England, and, indeed, our late advance in chymical knowledge having proved, that in these heterogeneous compositions, some of the ingredients entirely neutralise others, the Translator has occasionally substituted such more simple medicines as can be generally procured, and as are approved by the London College of Physicians. ${ }^{104}$

\footnotetext{
${ }^{95}$ Allgemeines Repertorium der neuesten in- und ausländischen Literatur, 1819, 1: 337-9, p. 339.

${ }^{96}$ Allgemeines Repertorium der Literatur, 1831, 3: 267-9, p. 268.

${ }_{97}$ Allgemeine Literatur Zeitung, 1819, 112: 42-8; 113: $50-2$.

${ }_{98}$ Orfila/Stevenson, 1826, pp. ii-iii. Stevenson said that "some considerations to Medical Jurisprudence; particular directions for conducting the Analysis of the poisons, and the Opening of the corpse; and the manner in which the Report of the investigating physician is to be drawn up, have been added in an Appendix. They were translated from 'A Medico-Legal Manual of Poisons' published in Paris, 1824, under the direction of Professor Chaussier". (See F Chaussier, Recueil de mémoires, consultations et rapports sur divers objets de médecine légale, Paris, T Barrois, 1824.) The appendix also contained information about "Treatment of the effects of lightning, prevention and treatment of the effects of drinking cold water, and means of rendering
}

assistance to persons drowning". This last part was just two pages long (pp. 229-30).

${ }_{99}$ Orfila/Black, Baltimore, 1819, title-page and pp. 219-25. The surgeon and antiquarian Thomas Joseph Pettigrew (1791-1865), who was the secretary of the Royal Humane Society, claimed to be the author of this section. See his autobiographical text in Medical portrait gallery, London, Fisher, Son, 1840, vol. 4, pp. 13-14.

${ }^{100}$ Orfila/Stevenson, 1826, p. 229.

${ }^{101}$ Cf. Orfila, 1825, p. 36, and Orfila/Stevenson, 1826 , p. 33. He also added footnotes taken from $\mathrm{J}$ Gorham, The elements of chemical science, Boston, Cummings and Hilliard, 1819-1820. See also Orfila/Stevenson, pp. 46, 51.

${ }^{102}$ See for instance, Orfila/Stevenson, p. 59,

[Of Emetine] "This proximate principle is somewhat differently described by Professor Bigelow".

${ }^{103}$ Orfila/Grimaud, 1826, p. 230, cf. Orfila, 1825 , pp. 21-7.

${ }^{104}$ Orfila/Black, 1819, Baltimore, pp. viii-ix. See pp. $89,170,134$, for additional examples. 


\section{A Popular Treatise on Poisons by Mateu Orfila (1818)}

This quotation shows the efforts translators made to adapt the book to their local audiences. Of course, the chemical and botanical terminology-particularly the local names of plants-posed enormous problems. Some translators attempted to transform Orfila's terms into local expressions, but sometimes many possible translations were available and ambiguities were common. ${ }^{105}$ Some mistakes were reported by contemporary reviewers. For instance, "tinture de tournesol" was translated into German as "Veilchensaft" instead of "Lackmus"- a major confusion between two different chemical indicators. ${ }^{106}$ The names of plants were especially difficult because Orfila had not always provided the Latin name. In fact, the English translators gave different versions for the same botanical term. ${ }^{107}$ The translator of the Boston edition (1826), Stevenson, added "the characters and effects of some [American] poisonous plants" which had not been "noticed by the author". ${ }^{108}$ Stevenson used books on American materia medica by Bigelow and Benjamin S Barton in order to add the data. ${ }^{109}$ He offered many synonyms and English botanical words but sometimes acknowledged that he could not find an English word for the animal or plant that Orfila had described. ${ }^{110}$ Perhaps these issues were in the mind of the German reviewer who remarked that the book had been written in France and that many poisons had a different effect in Germany, even if the dose was the same. ${ }^{111}$

In other cases, the overriding issue was the intended audience or the professional background of the translator. As noted above, many communities (surgeons, apothecaries, lay people) were not up to date with recent developments in chemical terminology, and may not have been particularly interested in the area. Black, a surgeon, did not provide the new names of chemical substances in his translation. For instance, in the case of antimony preparations, which had been used in pharmacy for many years, Black did not use terms such as "antimoniated tartrate of potash" or "deutoxide of antimony" but "emetic tartar, butter of antimony, Kermes mineral, golden sulphuret of antimony, submuriate of antimony, flowers of antimony, diaphoretic antimony, glass of antimony (crocus metallorum)". ${ }^{112}$ Clearly, Orfila and his translators had quite different attitudes towards the new terminology.

\footnotetext{
${ }^{105}$ Compare the English translation of Orfila/Price, 1818, and Orfila/Black, 1819, on mercurial preparations, arsenic, preparations of copper, epsom salt, etc. A similar situation arises in the case of the three Spanish translations. Compare Orfila, Madrid, 1818, Orfila/DJCP, 1824, and Orfila, Barcelona, 1842, for instance, names for magnesium sulphate (Epsom salt). The first edition (Orfila,

Madrid, 1818, p. 48) includes the local name "sal de Vacia-Madrid", which is in neither Orfila/DJCP, 1824 , p. 69, nor Orfila, Barcelona, 1842, p. 71.

${ }^{106}$ The mistake was reported by a contemporary reviewer, see Allgemeine Literatur Zeitung, 1819, 113: 50-2, p. 52.

${ }^{107}$ Compare, for instance, the translation of a list of irritant poisons by the surgeon R H Black (Baltimore, 1819) with the version by William Price (Philadelphia, 1818).

${ }^{108}$ Orfila/Stevenson, 1826, p. iii. The translation was very positively reviewed in The New England
}

\author{
Medical Review and Journal, 1827, 1: 141-7, which \\ offered some extracts. \\ ${ }^{109}$ Orfila/Stevenson, 1826 , p. 93 , poisonous \\ plants. He said that "those marked with an asterisk are \\ found native in this country". He included many \\ references to Barton's and Bigelow's books on \\ American botany and materia medica. \\ ${ }^{110}$ Orfila/Stevenson, 1826, p. 146. Class IV, In \\ section II, 'Of animals which may become \\ deleterious' he mentions "the clupaea thryssa" with a \\ footnote: "This is a fish about a foot in length, allied \\ to the herring, shad?, etc. I am ignorant of its English \\ name." \\ ${ }^{111}$ Allgemeines Repertorium der neuesten in- und \\ ausländischen Literatur, 1819, 1: 337-9, p. 338: \\ "dieses Werk in Frankreich geschrieben ist, wo \\ manche Gifte in gleicher Gabe anders wirken wie in \\ unserm [sic] nördlichen Deutschland". \\ ${ }^{112}$ Orfila/Black, 1819 , p. 58.
}




\section{José Ramón Bertomeu-Sánchez}

This example illustrates how translators were liable to change the intended audience of the book. By adding more popular terms and removing scientific ones, Black probably sought to make his book more appealing to lay audiences, apothecaries, and surgeons. In other cases, the changes are explicitly reported in the translator's introduction. Stevenson not only removed any reference to "physicians, surgeons, officiers de santé and apothecaries" from Orfila's introduction but also added a new introduction of his own in which he stated that the book had been adapted from Orfila's "great work on Poison", taking "those parts which should be within the reach of all, whose standing in society, or whose profession may render them liable to be called upon for aid and advice, in cases of accident or crime". Stevenson used "the third edition printed in Paris, 1825", from which Orfila had removed the references to lay audiences. The translator, however, repeated some of the arguments used by Orfila in his first edition:

Most of the cases of death by drowning, hanging, and poison, which are daily recorded in the public journals, proceed to their fatal termination only through the ignorance of those who, having the opportunity and the disposition to render aid, are destitute of the requisite means and knowledge. The frequency of these events sufficiently attests the necessity of a work of this kind, freed from technical language, and proposing remedies and means, which are procured and executed with the greatest facility. ${ }^{113}$

The changes introduced by translators could substantially modify important parts of the text, and suggested a broad spectrum of possible interpretations to their different intended audiences. In the American translation, Stevenson not only modified Orfila's comments on the intended readership in the introduction, but also the crucial section on the controversial topic of animal experimentation. He removed all critical references to Antoine Portal and to Orfila's defence of experiments on animals, which had been introduced in the second edition. ${ }^{114}$ Indeed, Stevenson added an appendix "on medicolegal considerations upon poisoning" (taken from another French book on toxicology), ${ }^{115}$ which raised serious doubts about the use of animal experimentation in toxicology. The arguments were similar to those used by Portal and other critics of animal experimentation:

Such trials are illusory and cannot lead to any positive result, nor can they serve to support an accurate comparison, since certain substances which man can employ with perfect safety, exert upon beasts the action of a violent poison; and vice-versa; the efforts that are made to force the animal to swallow, the violence employed to hold him, the ligature made on the oesophagus (itself an operation so painful that it may produce death), the mischievous qualities possessed by substances which, though not poisons, may be acrid and caustic, would not all these circumstances have an influence upon the result of the experiment? ${ }^{116}$

${ }^{113}$ Orfila/Stevenson, 1826, p. I, italics mine. The New England Medical Review and Journal, 1827, 1: 141-7, p. 143. Similar views were expressed in other American reviews. See the North American Medical and Surgical Journal, 1828, 6 (11): 151-3. Other views (more similar to Orfila's) were expressed by the Southern Review, 1831, 7: 297-319, p. 313.

\footnotetext{
${ }^{114}$ Orfila/Stevenson, 1826 , pp. 8-14. Compare Orfila, 1821, 2nd ed., pp. 1-15 with Orfila, 1825, pp. 1-15. Many paragraphs were erased.

${ }^{115}$ The book was Montmahou's, Manuel médicolégal des poisons, op. cit., note 68 above.

${ }^{116}$ Orfila/Stevenson, 1826, pp. 220-1.
} 


\section{A Popular Treatise on Poisons by Mateu Orfila (1818)}

Other authors also justified their opposition to animal experimentation on the grounds of the differences between human and animal physiology and anatomy and the unnatural conditions of vivisection experiments. ${ }^{117}$ However, it is surprising to read these critical comments inside a book in which many new antidotes were introduced with sentences such as "the result of the many trials we have made", "frequent direct experiments have proved", "we have proved by numerous and incontestable experiments", and so on. ${ }^{118}$ The example shows the rich (albeit restrained) creativity of translators who felt at liberty to revise and change a fair number of the key ideas of a book.

\section{The Dangers of Popularizing a Controversial Science}

In this paper, we have followed Orfila's Secours on its way from Parisian salons to remote American territories. Unlike Orfila's previous publications, the book was not addressed to the academic community but to a broad audience, including mayors, clergymen, heads of establishments and of families - those who might be called upon to "give immediate relief to the unhappy victims" of poisoning. The broad readership of the book explains why both Orfila and his translators regarded this work as a promising business venture, and indeed this must have been one of the main reasons for its publication and translation. The success of the book was largely due to the network of personal contacts that Orfila established thanks to his musical ability. The relation between toxicology and music highlighted here illustrates the importance of les relations du salon to the success of Orfila's book, through the influence of "persons of distinction" such as Comte de Molé. But much more difficult to grasp historically is how the life of the salons helped Orfila to obtain credibility, trust and academic power-all crucial ingredients in the public activity of a nineteenth-century toxicologist. Orfila regarded his book not only as a source of income but also as a way of bringing his ideas on antidotes and poisons, already presented to the academic community in his four-volume Traité des poisons, to a wider public. However, once it was published, Orfila lost control over the book, particularly when it reached the hands of creative readers and translators. By adding comments, footnotes and new passages, translators could expand the readership, adapt the book to their local audiences, or even blur one of the most important features of the original book, namely the role of experiments as a source of medical knowledge. Substantially changed by the translator, the book was more open to alternative meanings appropriated by readers in different local contexts, giving rise to a broad range of uses barely foreseen by Orfila-as the different reviews mentioned in this paper suggest.

The dissemination of the book coincided with a discussion on the effects of antidotes and the uses of animal experimentation. Controversy was part of the everyday life of nineteenth-century scientists and physicians. Journals, books and the proceedings of scientific sessions are full of examples. Many historical studies have focused on scientists' arguments on a wide variety of topics (theories, experimental data, the reliability of scientific instruments, among others), their reactions to these episodes, their strategies

\footnotetext{
${ }^{117}$ On early attacks against animal experimentation, see A-H Maehle and U Tröhler, 'Animal experimentation from Antiquity to the end of
} 


\section{José Ramón Bertomeu-Sánchez}

for recruiting allies, their underpinning assumptions, and so on. Less, however, has been written about the way in which scientific controversy undermines the public image of science when it reaches a lay audience, as happened in the case that concerns us here. ${ }^{119}$ In his famous study on the Wassermann test for syphilis, Ludwik Fleck noted the rising gradient of certainty from the core of expert publications to popular science, from the "esoteric" to the "exoteric" circle, from "personal and provisional journal science" to "collective, generally valid vademecum science". ${ }^{120}$ In a recent paper based on his studies on high-energy physics, Harry Collins has shown how experts are continually exposed to disputes with their colleagues and how their discussions remain openended for long periods of time. Outsiders are unable to grasp the nuances of the esoteric debates, much less participate in them; they learn the outcomes of science from "digested sources" (textbooks or popular books), in which there is no place for uncertainty. The danger arises when "sciences find themselves exposed to the public early on, before consensus has developed within the core-set". When the non-specialist public discovers that scientists argue with each other it loses faith in them: the scientific community loses credibility and its capacity of influence. ${ }^{121}$

From many points of view, early nineteenth-century toxicology is very different from the twentieth-century high-energy physics described by Collins. Toxicologists were not an established professional community made up of experts from similar backgrounds and engaged in similar activities. This explains the differences in their opinions on the value of clinical data, autopsies, and chemical tests. There was no defined, homogeneous core-set of experts. Moreover, toxicologists were always exposed to the public, obliged to face lay audiences in many contexts-journals, popular books, trials, newspapers, and so on. The history of Orfila's book shows that, as Ian Burney has remarked, there were frequent exchanges between popular, legal and medical cultures of poisons. ${ }^{122}$ Orfila's criticisms of "mistaken" popular practices show that he expected his book to meet some degree of resistance and rejection, because of the prior existence of a body of popular knowledge on poisons and antidotes. ${ }^{123} \mathrm{He}$ regarded the popularization of toxicology as desirable because "the preservation of ... poisoned individuals always depends upon the rapidity with which proper remedies are administered". ${ }^{124}$ But he had no wish to transform his readers into "physicians themselves" and, in many cases, he warned that treatments and tests should be conducted only by experts.

Orfila's "boundary work" was mostly based on the value of reliable experiments. Only trained toxicologists could perform accurate experiments and gather new information about the nature of poisons and their best antidotes. The new experimental protocols required a high degree of competence and access to laboratory resources that were available just to a small group of physicians and pharmacists. With his book, Orfila presented

\footnotetext{
${ }^{119}$ A very interesting case (on hypnotism and psychiatry) is offered by Ruth Harris, op. cit., note 54 above, see, for instance, pp. 172-6.

${ }^{120} \mathrm{~L}$ Fleck, Genesis and development of a scientific fact, University of Chicago Press, 1979, p. 120 .

${ }^{121} \mathrm{H}$ Collins and R Evans, 'The third wave of science studies: studies of expertise and experience', Soc. Stud. Sci., 2003, 32 (2): 235-96, pp. 247-8. The
}

ideas have been developed in H M Collins; R Evans, Rethinking expertise, Chicago, University Press, 2007.

${ }_{122}$ Burney, op. cit., note 1 above.

${ }^{123}$ For more examples, see Cooter and Pumfrey, op. cit., note 4 above.

${ }^{124}$ Orfila, 1818, Introduction, p. ix, translation Orfila/Price, 1818, p. i. 


\section{A Popular Treatise on Poisons by Mateu Orfila (1818)}

a new image of toxicology based on sophisticated chemical tests and animal experimentation. These pages have shown the complexity of this disciplinary change. As a result, Orfila faced resistance not only from his lay audience but from fellow medical men as well, including some of his translators who introduced many changes, critical remarks, and even opposing views on crucial issues such as animal experimentation. The controversies were remarked by many reviewers of the book, who noted the great variety of positions not only on the uses of experiments in medicine but also on the nature of poisons, the reliability of chemical tests, and the usefulness of antidotes and treatments. As in many other parts of early-nineteenth-century medicine and science, toxicology was never a consensual body of authorized knowledge that could be popularized top-down, from the academy to the lay public. Thus, the success and misfortunes of Orfila's Secours cannot really be understood by means of the diffusionist approach, applied to the transit of knowledge from expert to lay cultures or from the centre to the peripheries. The case analysed here suggests that more attention should be paid to the processes of exchange, appropriation and resistance in toxicology.

\section{Appendix}

\section{Editions and Translations}

\section{Secours à donner aux personnes empoisonnées}

The translations were published very soon after the first edition. Between 1818 and 1819, two English editions were published, (including two American reprints), along with three German translations, three Italian, one Danish and one Spanish. A new edition of R H Black's translation was published in 1820. The succeeding editions were less successful, though some translations into other languages were published in the following years.

\begin{tabular}{llllll}
\hline Language & Place & Publishers & Edition $^{a}$ & Year & Translator \\
\hline French $^{\mathrm{b}}$ & Paris & Chez l'auteur / Crochard & 1 & 1818 & \\
& Paris & Béchet jeune & 2 & 1821 & \\
& Paris & Béchet jeune & 3 & 1825 & \\
& Paris & Béchet jeune & 4 & 1830 & \\
Danish & Copenhagen & Hos Brummer & 1 & 1819 & C F Holmer \\
English & London & William Phillips & 1 & 1818 & W Price \\
& Philadelphia & Solomon W Conrad, & 1 & 1818 & W Price \\
& & Clark \& Raser & & & \\
& London & Longman & 1 & 1818 & R H Black \\
& Baltimore & Nathaniel G Maxwell & 1 & 1819 & R H Black \\
& London & Longman & 1 & 1820 & R H Black
\end{tabular}

Table continues 
José Ramón Bertomeu-Sánchez

Table (continued)

\begin{tabular}{|c|c|c|c|c|c|}
\hline Language & Place & Publishers & Edition $^{a}$ & Year & Translator \\
\hline & Boston & $\begin{array}{l}\text { Hilliard, Gray, } \\
\text { Little \& Wilkins }\end{array}$ & 3 & 1826 & $\begin{array}{l}\text { J G } \\
\text { Stevenson }\end{array}$ \\
\hline & London & $?$ & $?$ & $1838 ?$ & J Rennie ${ }^{c}$ \\
\hline \multirow[t]{4}{*}{ German } & Basel & Neukirch & 1 & 1818 & J A Roschet \\
\hline & Pest & Hartleben & 1 & 1819 & J Schuster \\
\hline & Berlin & Voss & 1 & 1819 & P G Brosse \\
\hline & Berlin & Vossische Buchhandlung & 4 & 1831 & J F John \\
\hline \multirow[t]{5}{*}{ Italian $^{\mathrm{d}}$} & Livorno & Vignozzi & 1 & 1818 & - \\
\hline & Palermo & Tip. F Abate & 1 & 1819 & - \\
\hline & Rome & Pio Cipicchia & 1 & 1819 & C Porta \\
\hline & Naples & Tip. Luca Martota & 1 & 1819 & $\begin{array}{l}\text { C Porta/P De } \\
\text { Philippis }^{\text {e }}\end{array}$ \\
\hline & Bologna & Riccardo Massi & 3 & 1827 & $\begin{array}{l}\text { V L, } \\
\text { "medical } \\
\text { doctor" }\end{array}$ \\
\hline Portuguese & Paris & P N Rougeron & $2 ?$ & 1823 & J F Tavares \\
\hline \multirow[t]{3}{*}{ Spanish } & Madrid & $\begin{array}{l}\text { Imprenta de la calle } \\
\text { de la Greda }\end{array}$ & 1 & 1818 & M Orfila [?] \\
\hline & Paris & Rosa & 1 & 1824 & D J C P \\
\hline & Barcelona & Imprenta de C y J Mayol & $1 ?$ & 1842 & - \\
\hline
\end{tabular}

${ }^{a}$ In the case of translation, the number shows the edition from which it was translated.

${ }^{\mathrm{b}}$ Another French edition was published in Brussels, Libraire Médicale et Scientifique, 1830.

${ }^{\mathrm{c}}$ This was, in fact, a chart summarizing Orfila's book. See The Chemist, 1843, 4: 239.

${ }^{\mathrm{d}}$ Some Italian editions were published under the title Tossicologia pratica del Professore Orfila: coll'aggiunta della medicina legale riguardante il veneficio ricavata dalle altre opere dello stesso professore. The last was published in Naples by F Rossi in 1845.

${ }^{\mathrm{e}}$ Tossicologia prattica, ovvero soccorsi da apprestarsi alle persone avvelenate o cadute in asfissia ... Tradotta dal francese in italiano dal dott. Carlo Porta con alcune annotazioni del dott. Pietro De Philippis, Naples, Tip. Luca Marotta, 1819. 